\title{
混合アルカリ塩蒸気と耐火物質との反応
}

\author{
山口明泉・咕 倉 光男 \\ (名古屋工業大学)
}

\section{Reactions between Vapors from Molten Mixed Alkali Salts and Refractory Materials}

\author{
By \\ Akira YAMAGUCHI and Mitsuo SAKAKURA \\ (Nagoya Institute of Technology, Nagoya)
}

\begin{abstract}
As a fundamental study on corrosion of refractories by alkali-containing vapor, the present study has been made for the purpose of researching the reactions occurred in the refractory materials such as corundum, mullite and forsterite when they were exposed to vapors from the melt of mixed salt, $\mathrm{K}_{2} \mathrm{CO}_{3}-\mathrm{Na}_{2} \mathrm{CO}_{3}$, at $1200^{\circ} \mathrm{C}$ and from the melt of mixed salt, $\mathrm{K}_{2} \mathrm{SO}_{4}-\mathrm{Na}_{2} \mathrm{SO}_{4}$, at $1300^{\circ} \mathrm{C}$.

In the tests with carbonate vapor, the reactions took place through two stages under the condition held in a steady vapor composition and at a constant temperature. At the early stage the mole ratio of $\mathrm{K}_{2} \mathrm{O}$ to $\mathrm{Na}_{2} \mathrm{O}$ found in the reaction products was almost the same as that in the vapor, whereas at the later stage the products were altered progressively into those richer in $\mathrm{Na}_{2} \mathrm{O}$ by replacing $\mathrm{K}$ in the products by $\mathrm{Na}$ in the vapor. In the respective cases of corundum, mullite and forsterite, the solid solutions of $\mathrm{K}$ - and $\mathrm{Na}-$ compounds as shown by the following formulas were formed, namely, $(\mathrm{K}, \mathrm{Na}) \mathrm{AlO}_{2}$, ( $\mathrm{K}$, $\mathrm{Na})_{3} \mathrm{Al}_{3} \mathrm{SiO}_{8}$ and $(\mathrm{K}, \mathrm{Na})_{2 x} \mathrm{Mg}_{x} \mathrm{Si}_{10-x} \mathrm{O}_{20}(4 \leqq x \leqq 5)$. During cooling, however, the solid solutions were separated into two phases of $\mathrm{K}$ - and $\mathrm{Na}$-compounds. Consequently, the amount of $\mathrm{Na}$-compounds in the reaction products increased with increasing time of reaction.

In comparison to the tests with carbonate vapor, the reaction velocity observed when tested with sulphate vapor were very sluggish, nevertheless, at the early stage of reaction the mole ratio of $\mathrm{K}_{2} \mathrm{O}$ to $\mathrm{Na}_{2} \mathrm{O}$ in the product was almost the same as that vapor also in this case.
\end{abstract}

[Received February 13, 1971]

\section{1. 緒畗}

高炉用あるいはガラス熔解箩用耐火物の損傷のなか でアアルカリよる侵蝕はもっとも曊著なものの1つで あり，従来よりこれに関方研究が数多く行なわれてき たが，その機構については，種々の要因が交錯して起こ 当ため, 複雑な様相在呈し詳らかでないところが多い。 なかでも，ナトリウム成分と力リウム成分が共存する場 合の信蝕譏構は，それぞれ単独成分によるよりるさらに 複雑になる。ただこの場含住，各具独成分による侵蝕の 組合わさったものと理解しても基本的には閒違いないと 考えるが, 侵蝕過程中の女る段階ごとにナトリウム成分 とカリウム成分の耐火物に影響する度合に差異が生ずる

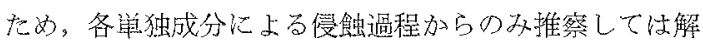
橎できないことも生ずる。また従来の研究で，両成分が 共存子る場合の侵蝕について诘，力リウム成分が将に州 火物中に残留富化し，侵蝕に主要な役割をなすとの報
告 ${ }^{12}{ }^{2}$ があるものの，その理由は究明されておらず，ア ル力リ混合蒸気による耐火物の信蝕㙨構については，ほ とんど解明されていないのが実箐である。

本研究性この点老明ら加にした日のである。すなわ ら, 岁らかしめナトリウム塩とカリウム塩の混合融液中 とそれから蒸発した蒸気中での $\mathrm{Na}_{2} \mathrm{O}$ と $\mathrm{K}_{2} \mathrm{O}$ の存在 割合の関係学調べ，それに基ついて，耐火物翼のなかで る主要な鉱物であるコランダム，ムライト就よびフォル ステライトを選び，それらとアルカリ混合蒸気との反応 過程中に就ける十トリウム成分と力リウム成分の挙動を 追管し，その反壳機構を究明したもので市。

\section{2. 害 験方 法}

2.1 試 料

つぎの耐火物質およざ耐火物についてアルカリ混合蒸 気との反応孛調べた。 
コランダム：酸化アルミニウム特級試薬を $1300^{\circ} \mathrm{C} て ゙$ 5 時間焼成したもの

ムライト：市販の合成ムライトで，前報3゙用いたの と同じブロックとそのブロックを粉末にしたもの

フォルステライト： $\mathrm{MgO} と \mathrm{SiO}_{2}$ 試薬を混合プレス 成形して, $1700^{\circ} \mathrm{C}$ て 5 時間焼成して合成したもの

フォルステライト耐火物：前報けて用いたものと同じ 60

\section{2 アルカリ混合蒸気組成, 測定}

アルカリ蒸気源用試薬として, $\mathrm{Na}_{2} \mathrm{CO}_{3}, \mathrm{~K}_{2} \mathrm{CO}_{3}, \mathrm{Na}_{2}$ 。 $\mathrm{SO}_{4}$ 括よび $\mathrm{K}_{2} \mathrm{SO}_{4}$ の各特級試薬学用いた。

まず $\mathrm{Na}_{2} \mathrm{CO}_{3}$ と $\mathrm{K}_{2} \mathrm{CO}_{3}$ 小よび $\mathrm{Na}_{2} \mathrm{SO}_{4}$ と $\mathrm{K}_{2} \mathrm{SO}_{4}$ の同一塩のものの混合比变えた試料を用意して，あら かじめこの試料の $17 \sim 18 \mathrm{~g}$ 老白金壮堝 $(10 \mathrm{cc})$ 中でバ 一ナで熔融し，この白金坩堝克白金管で内張りされた炉 中に入れ，図-1の上らに七ットした。 そして炭酸堭混

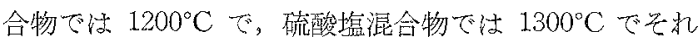
ぞれ 20 分間自然蒸発させて招さ，その中に水冷した銅 パイプ $(5 \mathrm{~mm} \phi)$ を 3 分間捙入して䳜気を付着させた。 その後炉中から取り出し，アルカリの村着した銅パイプ の下端から約 $2 \mathrm{~cm}$ までの部分学蒸溜水で洗浄し,この 洗浄水の炎光分析索行ない $\mathrm{K}_{2} \mathrm{O}$ ¿ $\mathrm{Na}_{2} \mathrm{O}$ の比率学求 め。

なお蒸気索採集する前のブランク実験では，銅パイプ 拉よび炉内加らのアルカリ成分は検出されなかった。

また蒸発による融液の組成変動は，融液試料が 17 $18 \mathrm{~g}$ で，実験中に打けるそれからの蒸発量は孷酸塩で $50 \mathrm{mg}$ 以下，硫酸塩で $25 \mathrm{mg}$ 以下，子なわちそれぞれ $0.3 \%, 0.15 \%$ 以下の蒸発量であり, 実験中の融液の組 成変動は無視できる值である。

\section{3 化合物の合成および高温 X 線回折装置による} 測定

反态過程中で生成する化合物の推移㐨よびそれらの化 合物の生成時での状態を調心゙るため，下記の試薬を使用

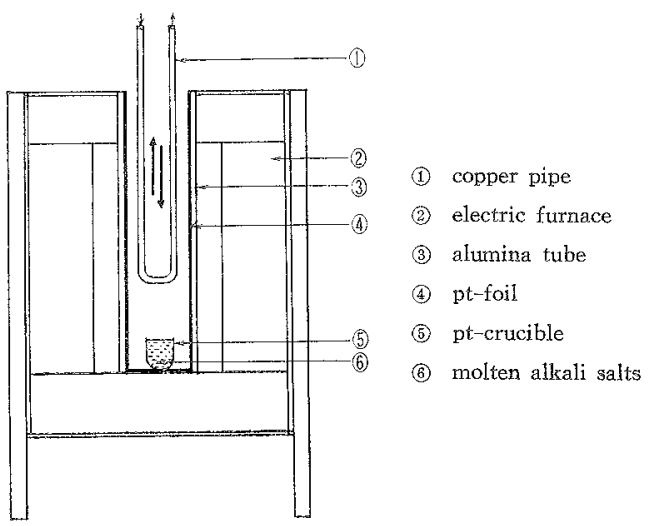

Fig. 1. Apparatus for pick-up of alkaline vapors.
し必要に応じて合成した。その際アルカリ化合物では焼 成中にアルカリがかなり蒸発しやすいので，それを防ぐ た所定の混合物をプレス成形し，それ字白金㘿堝に大 れ，その周囲に同一組成の粉末を充填し盍をして $1200^{\circ} \mathrm{C}$ で 3 時間焼成した。亦た高温での化合物の状態や化合物 間の固溶関係などを高温X線回折装監によって調べた.

化合物を合成寸るのに用いたのは次の試薬である。

$\mathrm{SiO}_{2}$ : 沈降製無水珪酸特級試薬

$\mathrm{MgO}$ : 炭酸マグネシウム特級試薬を $1400^{\circ} \mathrm{C}$ で 5 時 間焼成したもの

$\mathrm{NaAlO}_{2}, \mathrm{KAlO}_{2}: \mathrm{NaAlO}_{2}$ (c. p.) おるよ゙ $\mathrm{K}_{2} \mathrm{O}$.

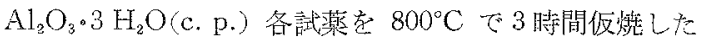
80

\section{$\mathrm{Na}_{2} \mathrm{CO}_{3}, \mathrm{~K}_{2} \mathrm{CO}_{3}$ : 各特級試薬}

\section{4 各語料のアルカリ蒸第処理}

各部料とアルカリ混合蒸気との反応による反応量変 化，生成化合物変化㜿よび反応アルカリ中の $\mathrm{K}_{2} \mathrm{O}$ と $\mathrm{Na}_{2} \mathrm{O}$ の割合などを求少るた，粉末にした各試料在次 の方法によってアルカリ蒸気処理した。この暢合，アル カリ混合融液として選び出したのは，炭酸塩の場合は $\mathrm{K}_{2} \mathrm{CO}_{3}$ と $\mathrm{Na}_{2} \mathrm{CO}_{3}$ との混合モル比が 1: 1 および 1: 4（以下をれそれを（1:1）炭酸塩，(1:4）炭酸塩と略 す) の 2 種類で, $1200^{\circ} \mathrm{C}$ に扣叮るそれぞれの蒸気とコ ランダム，ムライトおよび合成フォルスデライトとの反 志について調べた。硫酸塩の蒸気は、コランダムと合成 フォルステライトに刘してほとんど反応せずままたラ イトに対しても非常に反応が遅いので，ムライトについ てのみ， $\mathrm{K}_{2} \mathrm{SO}_{4}$ と $\mathrm{Na}_{2} \mathrm{SO}_{4}$ との等モル混合物（以下 (1：1）硫酸塩と略す）の蒝気との反応について調べた. ます，各試料とアルカリ混合蒸気との時間変化にとも

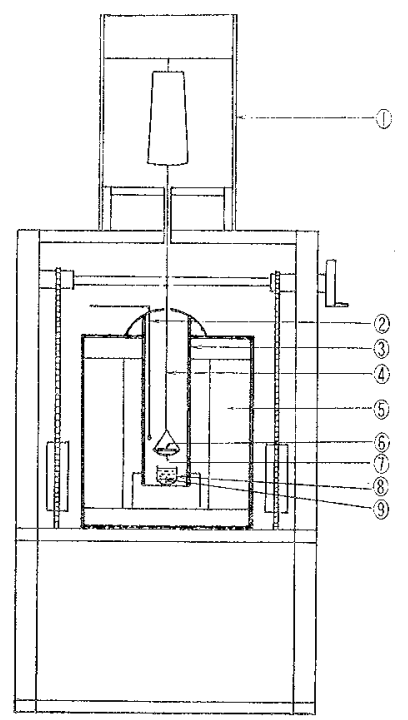
(1) balance
(2) thermocouple
(3) alumina tube
(4) Pt-wire
(5) electric furnace
(6) powder sample
(7) Pt-plate
(8) Pt-crucible
(9) molten alkali salts

Fig. 2. Apparatus for reaction between the powder samples and alkaline vapors. 
なら反応量の変化を調べるには，図-2 の装置を用いた。 この場合の試料は，全体が同時に蒸気と反応するよう に，指頭に感じない程度に微粉末にして，約 $50 \mathrm{mg}$ を $15 \mathrm{~mm}$ 平方の白金板上偟さ $0.06 \mathrm{~mm}$ 程度，広さ 13 $\mathrm{mm}$ 平方に搪代た，そしてこの白金板を白金亚上にの 世，それ孝熱天秤㴡白金線で吊し，アルカリ蒸気中に保 持するょらにして，反応に上って生ずる重量変化を測定 した。な扔実験中の融液組成の変動をできるだけ少なく

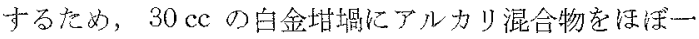
杯（約 $50 \mathrm{~g}$ ) 熔融してせットした.

次に，それぞれ反応過程中での生成物変化および反応 した $\mathrm{K}_{2} \mathrm{O}$ と $\mathrm{Na}_{2} \mathrm{O}$ 量の測定に供する試料は, 别個に 上記と同じ方法で蒸気处理し，種々の所定量のアルカリ と反応した時に炉中加らただらに空気中に取り出し急冷 して得た。 そしてX線分析によって生成物を同定し，末 た化学分析汇上って $\mathrm{K}_{2} \mathrm{O}$ < $\mathrm{Na}_{2} \mathrm{O}$ 量を求为在。生成 物の推移は，同一条件で分析した回折図形のそれぞれの 化合物の回折線のう台代表的な 1 つ選び，卡の強度変 化加ら求脄。したがって得られた結果のグラフは, 生 成化合物閵の量比起表わするのでなく，それぞれの化合 物の消長の推移を表为古ものである。な拉X線分析する 試料で，空気中で吸湿性のあるものについては，炉から 取り出すとただちにツェーダ油に入れ吸湿を防いだ。
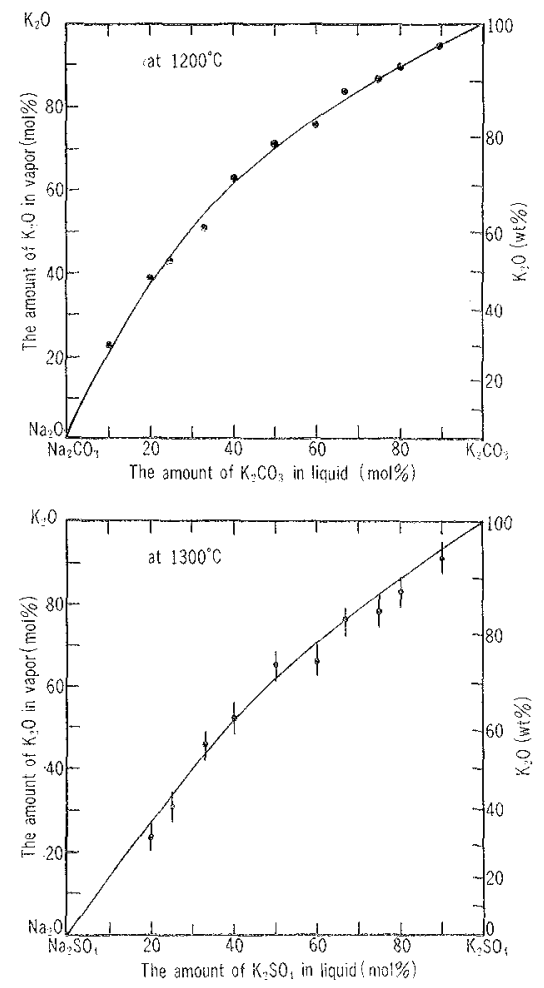

Fig. 3. The ratio of $\mathrm{K}_{2} \mathrm{O}$ to $\mathrm{Na}_{2} \mathrm{O}$ in vapor of molten $\mathrm{K}_{2} \mathrm{CO}_{3}-\mathrm{Na}_{2} \mathrm{CO}_{3}$ mixtures at $1200^{\circ} \mathrm{C}$ and molten $\mathrm{K}_{2} \mathrm{SO}_{4}-\mathrm{Na}_{2} \mathrm{SO}_{4}$ mixtures at $1300^{\circ} \mathrm{C}$, respectively.
また，合成ムライトとフォルステライト耐火物のそれ ぞれのブロック試料のアルカリ蒸気処理は，前報》を同 様の方法で行ない， $1200^{\circ} \mathrm{C}$ に扔ける $(1: 1)$ 炭酸塩蒸 気によるムライトとフォルステライト耐火物の侵蝕抒よ び $1300^{\circ} \mathrm{C}$ に和汀る (1: 1) 硫酸塩蒸気によるムライト の侵蝕について調べた。

\section{3. 窫 験 結 果}

\section{1 アルカリ混合融液中とその蒸気中の $\mathbb{K}_{2} \mathrm{O}$ と $\mathrm{Na}_{2} \mathrm{O}$ の割合の関係}

図-3 法 $1200^{\circ} \mathrm{C}$ の炭酸塩混合融液中および $1300^{\circ} \mathrm{C}$ の硫酸塩混合融液中と乞扎加蒸発した蒸気中の $\mathrm{K}_{2} \mathrm{O}$ と $\mathrm{Na}_{2} \mathrm{O}$ の割合の関係を表わしたもので等る。

それによると，炭酸塩に招いていずれの組成でも蒸気 中の $\mathrm{K}_{2} \mathrm{O}$ の割合治融液中のそれよりも多くなっている。 たとえば，等モル炭酸塩混合融液加ら蒸発した蒸気中の $\mathrm{K}_{2} \mathrm{O}$ と $\mathrm{Na}_{2} \mathrm{O}$ の割合は 70/30 ( $\mathrm{mol}$ 比)で岁る。

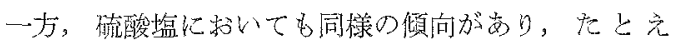

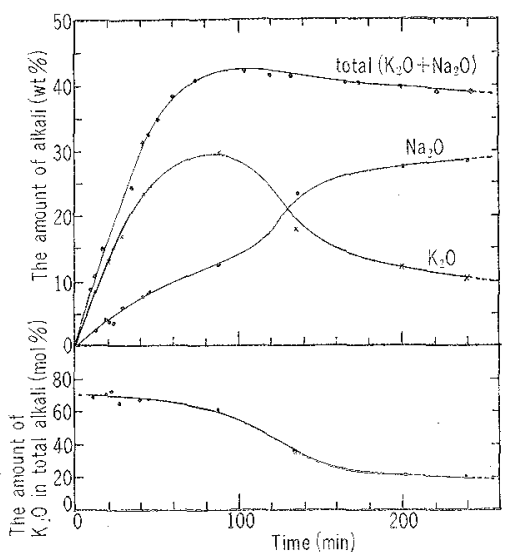

(a) in vapor of molten $\mathrm{K}_{2} \mathrm{CO}_{3} \cdot \mathrm{Na}_{2} \mathrm{CO}_{3}$

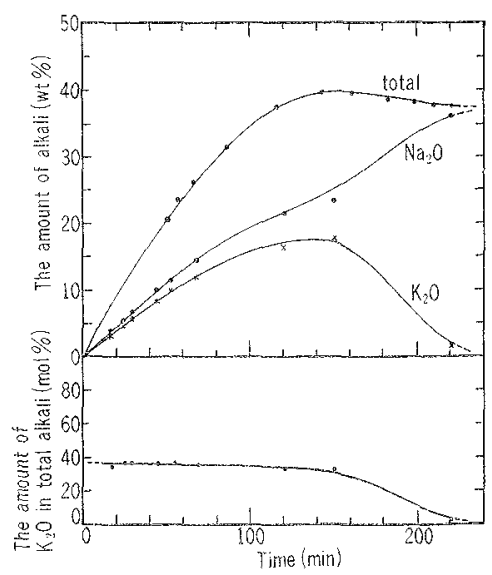

(b) in vapor of molten $\mathrm{K}_{2} \mathrm{CO}_{3} \cdot 4 \mathrm{Na}_{2} \mathrm{CO}_{3}$

Fig. 4. Changes of the amount of alkali picked up by the alumina powder samples during exposure to vapor of molten $\mathrm{K}_{2} \mathrm{CO}_{3} \cdot \mathrm{Na}_{2} \mathrm{CO}_{3}$ and molten $\mathrm{K}_{2} \mathrm{CO}_{3} \cdot 4 \mathrm{Na}_{2} \mathrm{CO}_{3}$ at $1200^{\circ} \mathrm{C}$, respectively. 
ば，等モル硫酸塩混合融液加ら蒸発した寮気中の $\mathrm{K}_{2} \mathrm{O}$ と $\mathrm{Na}_{2} \mathrm{O}$ の割合は 60/40 ( $\mathrm{mol}$ 比) で方。しかし炭 酸塩の場合心比較すると, 融液組成比と蒸気組成比しの 差が少なくなっている。

\section{2 コランダムとアルカリ炭酸嵒混會蒸氛しの反応}

\section{2 .1 アルカリ反応量战よび生成物变化 $1200^{\circ} \mathrm{C}$} に扔いて，(1:1) および (1:4) 炭酸湓のそれぞれの䓠 気とコランダムとの反応によって生ずるアルカリの反応 量変化拉よび反応したアルカり中の $\mathrm{K}_{2} \mathrm{O} / \mathrm{Na}_{2} \mathrm{O}$ 比の変 化妾図-4 に示古. いずれも反応初期の未反応コランダ ムが残存している䦔に反応した $\mathrm{K}_{2} \mathrm{O} / \mathrm{Na}_{2} \mathrm{O}$ 比は，(1：

1) 拉よび (1:4) 炭酸塩蒸気との反灾において, それぞ れ 70/30，37/63 (mol 比) 七なり，3.1 の結果で求めた 蒸気中の割合とかなりよく一致してい当。しかし反底の 進行につれて $\mathrm{Na}_{2} \mathrm{O}$ 湴加虫続けるものの, これに反 L $\mathrm{K}_{2} \mathrm{O}$ の侵大速度は次第に遅くなり，やがて放出が拈 こり，減少するようになる。その結果，アル力リ艾応量 の合計法減少し，孙つ $\mathrm{K}_{2} \mathrm{O} / \mathrm{Na}_{2} \mathrm{O}$ 比は次第火小さくな 万.

また，この反応によって生成する化合物は $\mathrm{NaAlO}_{2}$ と $\mathrm{KAlO}_{2}$ のみであり，これらは反応初期に其存して生 成するものの, $\mathrm{K}_{2} \mathrm{O} / \mathrm{Na}_{2} \mathrm{O}$ 比の変化にとるない次第に $\mathrm{KAlO}_{2}$ の減少と $\mathrm{NaAlO}_{2}$ の增加がもたらされ，ほとん と $\mathrm{NaAlO}_{2}$ のみになるまでに変化する。 X線分析結果 の代表例として，図-5に，(1:1）炭酸塩蒸気との反応 で末反応コランダムが残存している仪怘初期の試料，ア ルカリ反心量が最大になった反応中期の試料および反応 がもっともよく進办反応量変化が活とんどなくなった反 応後期の試料，才なわち，アル力リ区応量が $28.8,42.2$ 捛よび 37.8 wt\% の回折図形を示したが，最後の試料 では $\mathrm{NaAlO}_{2}$ のみの回折線を与える。

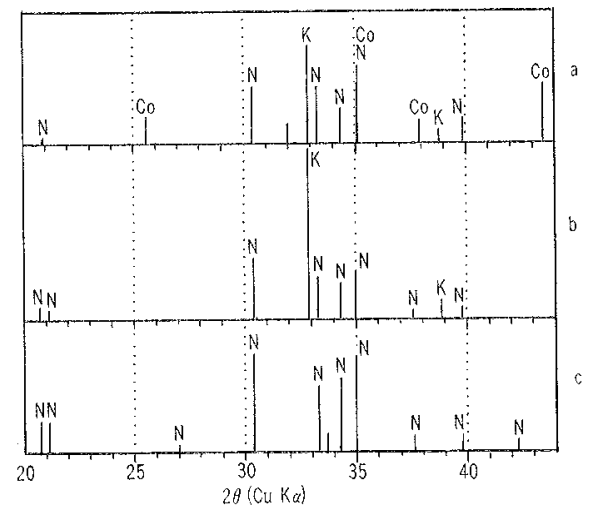

$\mathrm{C}_{0}: \alpha-\mathrm{Al}_{2} \mathrm{O}_{3} \quad \mathrm{~K}: \mathrm{KAlO}_{2} \quad \mathrm{~N}: \mathrm{NaAlO}_{2}$

(a) initial stage (28.8 wt\% alkali)

(b) middle stage $(42.2 \mathrm{wt} \%$ alkali)

(c) final stage $(37.8 w \mathrm{t} \%$ alkali)

Fig. 5. X-ray diffraction patterns of the corundum powder samples reacted with vapor of molten $\mathrm{K}_{2} \mathrm{CO}_{3} \cdot \mathrm{Na}_{2} \mathrm{CO}_{3}$ at $1200^{\circ} \mathrm{C}$.
$3.2 .2 \mathrm{NaAlO}_{2}$ Ł $\mathrm{KAlO} \mathrm{O}_{2}$ との関係コランダム とアルカリ混含蒸気との反応に際し，其存して生成寸る $\mathrm{NaAlO}_{2}$ と $\mathrm{KAIO}_{2}$ の混弇物について, 叚度温度 $\left(1200^{\circ} \mathrm{C}\right)$ くの状態, 拈よびそれ常温むで冷却した坊 合の状態らついて調べた結稌である。

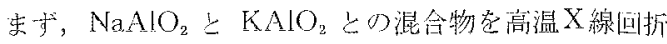
装置によって，1200 C での状熊を調べた結果，罒-6に

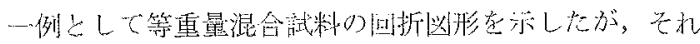
に上ると，立方晶の1つの結晶となって招り，雨者はこ の温曼で固溶体を形成することを示す。

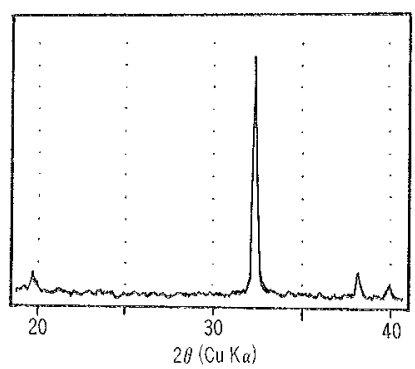

Fig. 6. X-ray diffraction pattern of the mixtures of $\mathrm{NaAlO}_{2}(50 \mathrm{wt} \%)$ and $\mathrm{KAlO}_{2}(50 \mathrm{wt} \%)$ at $1200^{\circ} \mathrm{C}$.

また，別に $\mathrm{NaAlO}_{2}$ と $\mathrm{KAlO}_{2}$ の種々の割合の混合 物を白金坩垛に入れ， $1200^{\circ} \mathrm{C}$ で 3 時間焼成した後，常 温まで泠却した試料のX線分析では, $\mathrm{NaAlO}_{2}$ と $\mathrm{KAlO}_{2}$ のそれぞれの回折線が現われ，目溶体の形成老示さない。

つぎに， $\mathrm{NaAlO}_{2}$ と $\mathrm{KAlO}_{2}$ のそれぞれを $1200^{\circ} \mathrm{C} の$ (1：1）炭酸塩蒸気中に保持した場合， $\mathrm{NaAlO}_{2}$ ではほ とんど変化が認められなかったが，これに反し， $\mathrm{KAlO}_{2}$ では次第にナトリウムの多いものになり， $\mathrm{NaAlO}_{2}$ に変 化した。

\section{3 ムライイトと炭酸塩混合蒸気との反応}

3.3.1 ムライト微粉末による策験結果 $1200^{\circ} \mathrm{C}$ に 招ける(1：1) および (1：4) 炭酸塩蒸気との反応によ るアルカリ反応量の変化，反応アルカリ中の $\mathrm{K}_{2} \mathrm{O} / \mathrm{Na}_{2} \mathrm{O}$ 比の変化および生成化合物の変化を図 -7 に示す。

(1: 1) 蒸気との反応は，(1:4) 蒸気との反応よりも 早いが，い寸゙れもムライトが残存している間の反壳は早

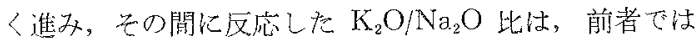
70/30, 後者では 44/56 となり，ほぼ蒸気中のてれと一 致している。しかし，ムライトが消失した後には， $\mathrm{K}_{2} \mathrm{O}$ の侵入は遅くなり，やがて逆に放出により減少を始就 る。これに戈し， $\mathrm{Na}_{2} \mathrm{O}$ は增加甞続ける。常温で求めた 生成物子ほぼそれに対店して変化して抒り，反応初期の ムライトが残存している試料では，力ルシライトが生成 古るもののムライトの消失とともにななり， $\mathrm{K}_{2} \mathrm{O}$ 。 $\mathrm{Al}_{2} \mathrm{O}_{3} \cdot \mathrm{SiO}_{2}-\mathrm{K}_{2} \mathrm{O} \cdot \mathrm{Al}_{2} \mathrm{O}_{3}{ }^{6\rangle} \mathrm{ss}$ (吉方晶系, 後に記すより Na 老国溶していると㫴えられるが，便宜上以下 KAS-

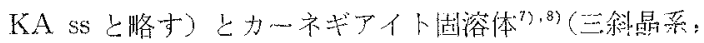




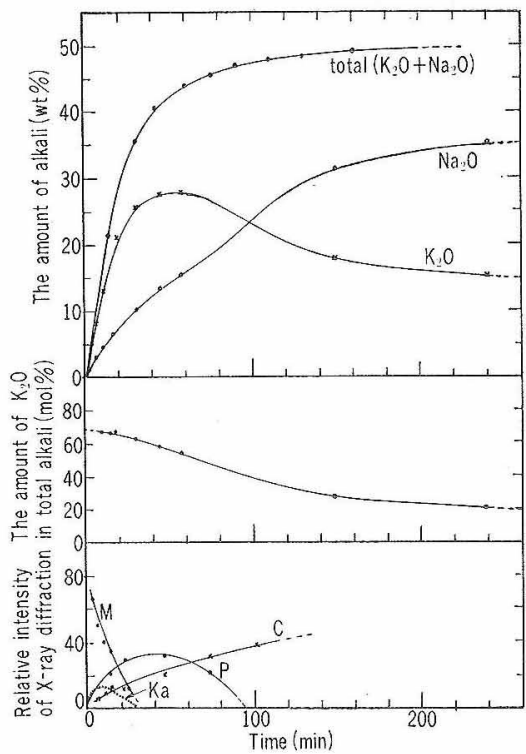

(a) in vapor of molten $\mathrm{K}_{2} \mathrm{CO}_{3} \cdot \mathrm{Na}_{2} \mathrm{CO}_{3}$

$$
\mathrm{M}: \text { mullite, } \quad \mathrm{Ka}: \text { kalsilite, } \quad \mathrm{P}: \mathrm{KAS}-\mathrm{KA} \text { ss } \quad \mathrm{C}: \text { carnegieite ss }
$$

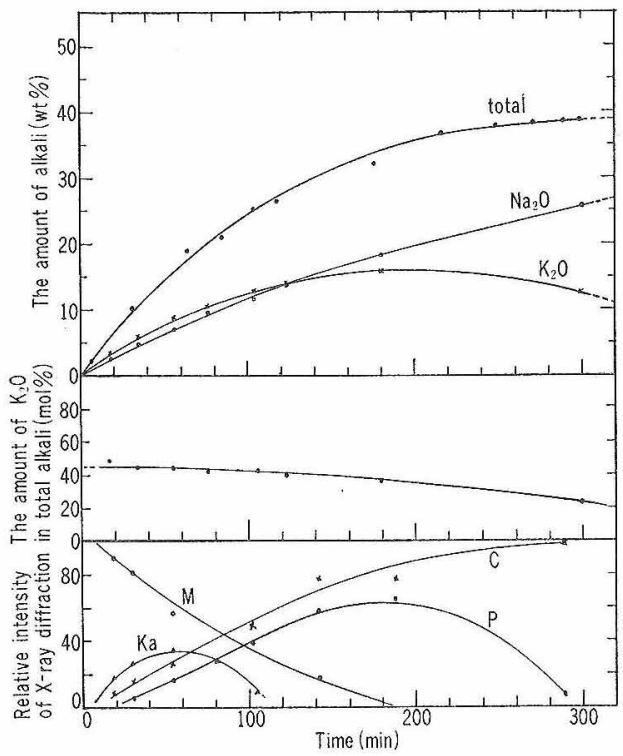

(b) in vapor of molten $\mathrm{K}_{2} \mathrm{CO}_{3} \cdot 4 \mathrm{Na}_{2} \mathrm{CO}_{3}$

Fig. 7. Changes of the amount of alkali picked up by the mullite powder samples and reaction products during exposure to vapor of molten $\mathrm{K}_{2} \mathrm{CO}_{3} \cdot \mathrm{Na}_{2} \mathrm{CO}_{3}$ and molten $\mathrm{K}_{2} \mathrm{CO}_{3} \cdot 4 \mathrm{Na}_{2} \mathrm{CO}_{3}$ at $1200^{\circ} \mathrm{C}$ respectively.

後に記すようにKを固溶していると考えられるが，便宜 上以下必要に応じて $\mathrm{NAS}_{2}-\mathrm{NAss}$ と略す) のみにな\% が，前者は $\mathrm{K}_{2} \mathrm{O}$ の減少するに伴い少なくなり，次第に 後者のみになっていく。

\subsection{2 ムライトブロックの侵蝕 $\quad 1200^{\circ} \mathrm{C}$ の $(1: 1)$} 炭酸塩蒸気によって 20 時間侵蝕されたムライトブロッ クの侵蝕層部分の顕微鏡写真, 括よび表面から順次 $50 \%$ 程度ずっ研削し，それぞれの研削面にX線を照射して得 られた回折図形のらちの代表的な 4 ケ所の図形を図-8 に示した、それによると、ルーサイトとカルシライトが
ムライト素地中に生成されているものの，主疛侵蝕壂は 加なり明瞭な $200 \mu$ 程度の層をなして形成されて拉り， ムライトは全く消失している，そしてその侵蝕層はほぼ 2 層に区別できる．第 1 層は表面より測定して 60〜200

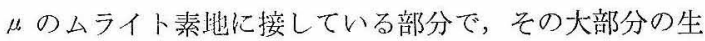
成物は，KAS-KA ss であり，5１3 析出している．しかし，ところどころ複屈折のある結晶 があり，カーネギアイト固溶体が混在して晶出している ことを示している，そして第1層の外部である第 2 層, すなわち表面から約 $60 \mu$ までの部分は，複屈折のある

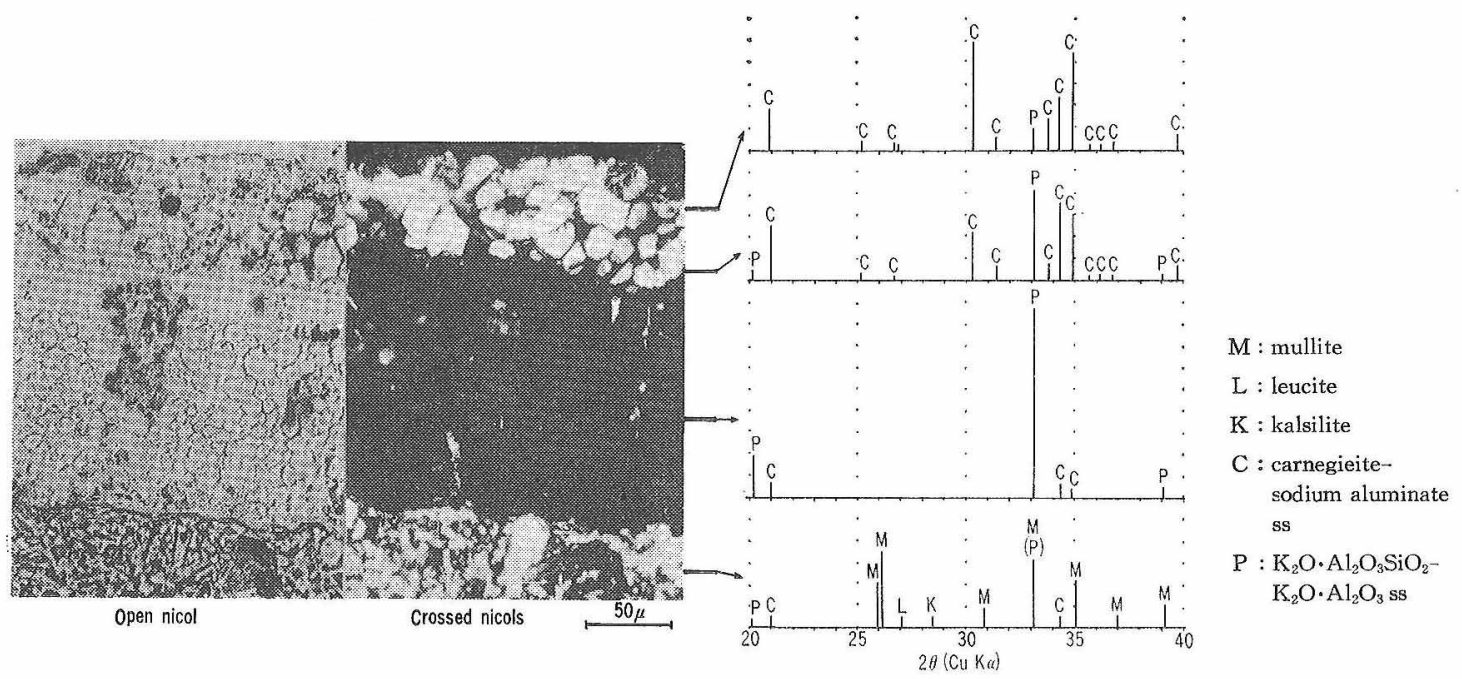

Fig. 8. Photomicrographs and $\mathrm{X}$-ray diffraction patterns of the mullite refractory attacked by vapor of molten $\mathrm{K}_{2} \mathrm{CO}_{3} \cdot \mathrm{Na}_{2} \mathrm{CO}_{3}$ at $1200^{\circ} \mathrm{C}$, for $20 \mathrm{hrs}$, 
カーネギアイト固溶体が $10 \sim 25 \mu$ のほほ球状をなて 析出し，その大部分の結晶が双晶美している。

3.3 .3 反店生成物間の関係上記の結果で, ムラ イトが完全に消失した時点の反応生成物は KAS-KA ss と $\mathrm{NAS}_{2}-\mathrm{NAss}$ であり, 全体としてはムライト組成比 を有子る $3\left(\mathrm{Na}_{2} \mathrm{O}, \mathrm{K}_{2} \mathrm{O}\right)-3 \mathrm{Al}_{2} \mathrm{O}_{3}-2 \mathrm{SiO}_{2}$ 組成化なっ いると考えてよいので，この組成党有するものの高温款 よび常温での状態を調べた。

すなわち， $\mathrm{NAS}_{2}-2(\mathrm{NA})$ ss (以下 $\mathrm{N}_{3} \mathrm{~A}_{3} \mathrm{~S}_{2}$ と略す) と 2(KAS)-KA ss (以下 $\mathrm{K}_{3} \mathrm{~A}_{3} \mathrm{~S}_{2}$ と略す) をとれぞれ 合成し，それらを種々の㓶合に混合し，そ机らの高温と 常温での状態を譯べた。

そのX線分析結果のうち, 1 例として, 図-9 亿等重 量混合物の $900^{\circ} \mathrm{C}$ とそれを常温亦で泠却したものの回 折図形を示したが，約 $800^{\circ} \mathrm{C}$ 以上では，それらの混合 物は立方晶の 1 つの結晶となり，また $900^{\circ} \mathrm{C}$ で測定し た格子定数任, 図-10 亿示すよう亿直線的に変化して, 両者の化合物間ではいずれの混合比のものも反応温度の

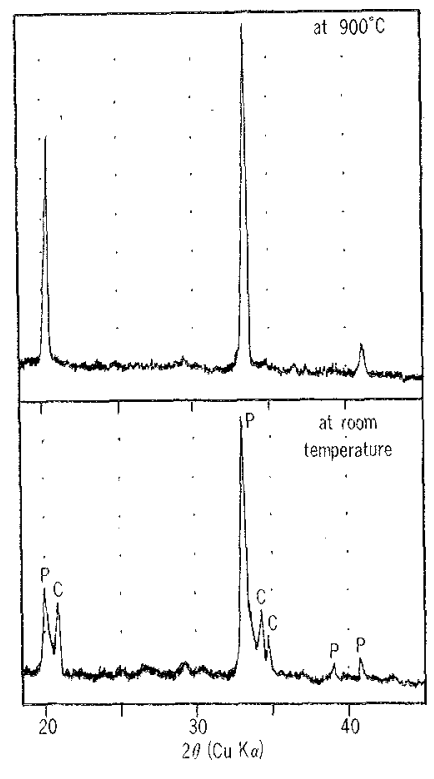

$\mathrm{P}: \mathrm{K}_{3} \mathrm{~A}_{3} \mathrm{~S}_{2} \quad \mathrm{C}: \mathrm{N}_{3} \mathrm{~A}_{3} \mathrm{~S}_{2}$

Fig. 9. X-ray diffraction patterns of the mixtures of $\mathrm{K}_{8} \mathrm{~A}_{8} \mathrm{~S}_{2}(50 \mathrm{wt} \%)$ and $\mathrm{N}_{3} \mathrm{~A}_{3} \mathrm{~S}_{2}(50 \mathrm{wt} \%)$ at $900^{\circ} \mathrm{C}$ and room temperature.

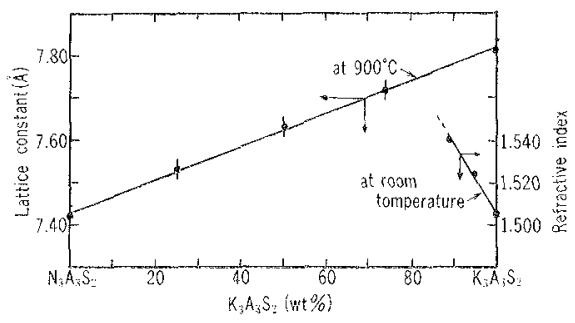

Fig. 10. Latlice constant (at $900^{\circ} \mathrm{C}$ ) and refractive index (at room temperature) of $\mathrm{K}_{8} \mathrm{~A}_{3} \mathrm{~S}_{2}-\mathrm{N}_{3} \mathrm{~A}_{8} \mathrm{~S}_{2} \mathrm{ss}$. $1200^{\circ} \mathrm{C}$ では固溶体を形成することを示している。そし てこれら常温まで徐泠した試料のらちで $\mathrm{K}_{3} \mathrm{~A}_{3} \mathrm{~S}_{2}$ に $\mathrm{N}_{3} \mathrm{~A}_{3} \mathrm{~S}_{2}$ の $11 \mathrm{wt} \%$ 添加の試料注, 立方晶の一相である が, 15 wt \% 添加の試料には少量ながら複屈折のある結 晶が混在して現われ, 常温での $\mathrm{K}_{3} \mathrm{~A}_{3} \mathrm{~S}_{2}$ への $\mathrm{N}_{3} \mathrm{~A}_{3} \mathrm{~S}_{2}$ の固溶限界が 11 15wt％であることを示寸。この固 溶体を生成す方範囲の屈折率変化は, 図-10に示すごと くである。

また，別に $\mathrm{N}_{3} \mathrm{~A}_{3} \mathrm{~S}_{2}$ と $\mathrm{K}_{3} \mathrm{~A}_{3} \mathrm{~S}_{2}$ のをれぞれを $1200^{\circ} \mathrm{C}$ の (1: 1) 炭酸塩蒸気中に保持すると, $\mathrm{N}_{3} \mathrm{~A}_{3} \mathrm{~S}_{2}$ 注汪と んど変化しないが，これに反し $\mathrm{K}_{3} \mathrm{~A}_{3} \mathrm{~S}_{2}$ は㳄第にナトリ ウムに富んだものになり $\mathrm{N}_{3} \mathrm{~A}_{3} \mathrm{~S}_{2}$ に変化した。

\section{4 ムライトと硫酸塩混合蒸気との反応}

$1300^{\circ} \mathrm{C}$ に挆汀子 $(1: 1)$ 硫酸塩蒸気とムライトとの 反応結果堂図-11 に示吉，この反応山，炭酸塩蒸気との 反応と比較して極端仁緩慢である。

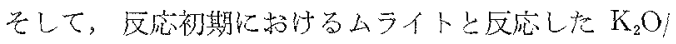
$\mathrm{Na}_{2} \mathrm{O}$ 比注, 蒸気中のその比率によく一致して叔り，60/ 40 (mol 比) である。しかし，それもムライトが消失寸 る頃から次第化小さくなる。

また，生成物はコランダム，カルシライト，カーネギ アイト固溶体叔よび $\beta$ アルミナであり， $\beta$ アルミナな コランダムが減少寸る頃から生成される，そして炭酸塩

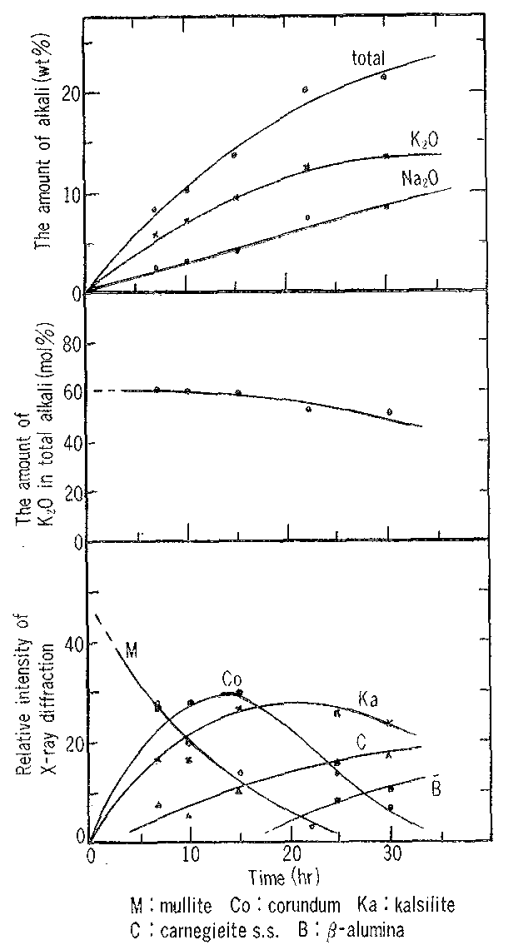

Fig. 11. Changes of the amount of alkali picked up by the mullite powder samples and reaction products during exposure to vapor of molten $\mathrm{K}_{2} \mathrm{SO}_{4} \cdot \mathrm{Na}_{2} \mathrm{SO}_{4}$ at $1300^{\circ} \mathrm{C}$. 
蒸気との反応によって生成する KAS-KAss は生成さ れない。

つぎに, $1300^{\circ} \mathrm{C}$ で 20 時間, (1:1) 硫酸塩蒸気で侵 蝕されたムライト・ブロックの顕微鏡写真を図-12 に示 すが，コランダムがムライト素地中に針状に著しく生成 し，また，表面から $30 \mu$ までの部分は，かなりはっき りした侵蝕層の形成が恋められる。この層には，X線分 析によると，力ルシライト，及ーアルミナ，力ーネギアイ 卜固溶体が生成しているが，生成結晶が微細な集合体と なって析出しているため，それぞれの結晶を顕微鏡下で は見分けられない。

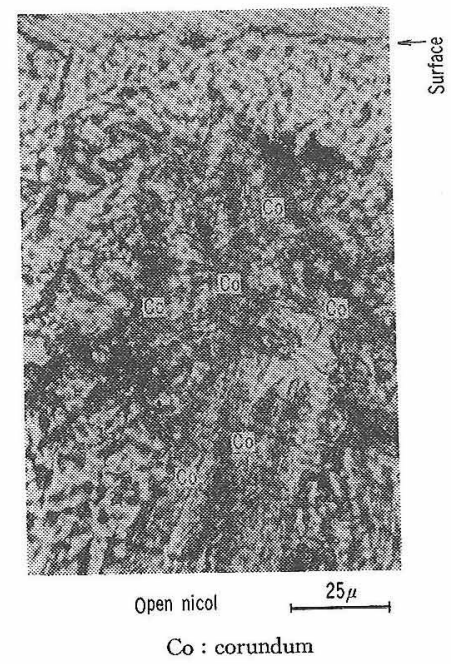

Fig. 12. Photomicrograph of the mullite refractory attacked by vapor of molten $\mathrm{K}_{2} \mathrm{SO}_{4} \cdot \mathrm{Na}_{2} \mathrm{SO}_{4}$ at $1300^{\circ} \mathrm{C}$, for $20 \mathrm{hrs}$.

\section{5 フォルステライトと炭酸塩混會蒸気との反岕}

\section{5 .1 生成化合物について 前報} イトのアルカリ蒸気による侵蝕の際に生成する化合物に ついて調ベ，炭酸カリウム蒸気による侵飿では $\mathrm{K}_{2} \mathrm{O}$ ・ $\mathrm{MgO} \cdot \mathrm{SiO}_{2}$ (以下 KMS と略す) と $\mathrm{MgO}$, 炭酸なトリ ウム蒸気による侵蝕では $2 \mathrm{Na}_{2} \mathrm{O} \cdot 2 \mathrm{MgO} \cdot 3 \mathrm{SiO}_{2}-\mathrm{Na}_{2} \mathrm{O}$ 。 $\mathrm{MgO} \cdot \mathrm{SiO}_{2}$ ss (以下 $\mathrm{N}_{2} \mathrm{M}_{2} \mathrm{~S}_{3}-\mathrm{NMS}$ ss と略す) と $\mathrm{MgO}$ であることを報告した.これらのことより，アルカリ混 合蒸気とフォルステライトとの反応によって, $\mathrm{N}_{2} \mathrm{M}_{2} \mathrm{~S}_{3}$ NMSss KMS の混合物あるいは固溶体の生成が予 想されたので，本実験結果は，それらの混合物の反応温 度での状態莸中心に調べたものである。

図-13は，1例として， $\mathrm{N}_{2} \mathrm{M}_{2} \mathrm{~S}_{3}$ と KMS の等重量 混合物をいったん $1300^{\circ} \mathrm{C}$ まて焼成したものの $1.000^{\circ} \mathrm{C}$ での回折図形および NMS と KMS の等重量混合物の $1100^{\circ} \mathrm{C}$ での回折网形であるが，これによると，いずれ 81つの立方晶の結晶となり，また図-14 に示されるよ うに，NMS と KMS の混合物の $1100^{\circ} \mathrm{C}$ での格子定 数は直線的に変化しており，これらのことは， $\mathrm{N}_{2} \mathrm{M}_{2} \mathrm{~S}_{3}-$

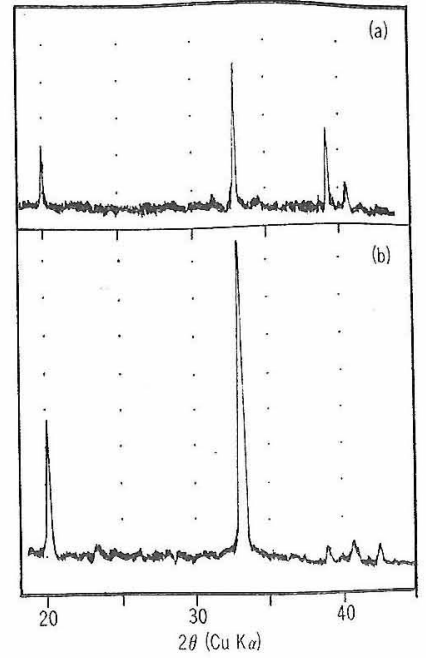

(a) $\mathrm{N}_{2} \mathrm{M}_{2} \mathrm{~S}_{3}(50 \mathrm{wt} \%)-\mathrm{KMS}(50 \mathrm{wt} \%)$ (b) NMS (50 wt \%)-KMS (50wt \%)

Fig. 13. X-ray diffraction patterns of $\mathrm{N}_{2} \mathrm{M}_{2} \mathrm{~S}_{3}-\mathrm{KMS}$ mixtures at $1000^{\circ} \mathrm{C}$ and NMS-KMS mixtures at $1100^{\circ} \mathrm{C}$.

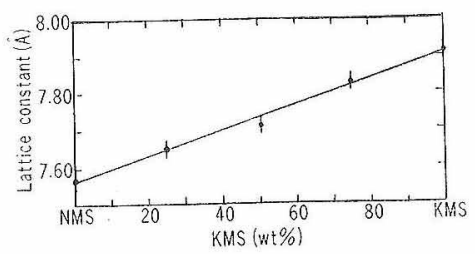

Fig. 14. Lattice constant of NMS-KMS ss at $1100^{\circ} \mathrm{C}$.

NMS-KMS 化合物間にお゙いて，少なくともこれ以上の 温度では，いずれの混合比のものも阋溶体を形成するこ とを示している。

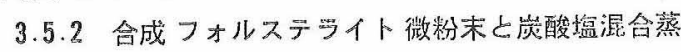
気との反応 $1200^{\circ} \mathrm{C}$ に捛ける合成フォルステライト と(1:1) および $(1: 4)$ 炭酸塩蒸気との反応によるアル カリ反応量変化, 拉よび反㐫アルカリ中の $\mathrm{K}_{2} \mathrm{O} / \mathrm{Na}_{2} \mathrm{O}$ 比 の変化を図-15 に示す. それによると，未反心フォルス テライトの残存する反応初期の $\mathrm{K}_{2} \mathrm{O} / \mathrm{Na}_{2} \mathrm{O}$ 比は, 耐者 の場合とも蒸気妕のそにかなりよく一致している。し かし，さらに应灾が進むに伴い，い。たん反応した $\mathrm{K}_{2} \mathrm{O}$ が放出されて減少し，一方 $\mathrm{Na}_{2} \mathrm{O}$ は増加を続け，その結 果 $\mathrm{K}_{2} \mathrm{O} / \mathrm{Na}_{2} \mathrm{O}$ 比は小さくなる。 そして, 常温で求めた 反灾生成物は, KMS, $\mathrm{N}_{2} \mathrm{M}_{2} \mathrm{~S}_{3}-\mathrm{NMS}$ sS (X線回折線飞 幾分のずれのあることから，それぞれ $\mathrm{Na}$ あるいは $\mathrm{K}$ を多少固溶すると考えられる)および $\mathrm{MgO}$ であり，X 線分析によると，区応初期には，KMS と MgOが現わ れ，区応の進行に伴い $\mathrm{N}_{2} \mathrm{M}_{2} \mathrm{~S}_{3}-\mathrm{NMS}$ ss が現われ，同 時に KMS の回折強度は小さくなる，

図-16 は，未反応フォルステライトが残存しており， アルカリ反応量が $16.7 \mathrm{wt} \%$ の試料と, フォルステラ イトが消失し，アルカリ区応量が $31.2 \mathrm{wt} \%$ の試料の 


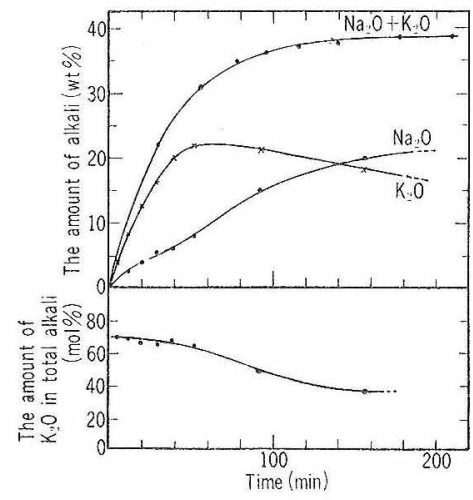

(a) in vapor of molten $\mathrm{K}_{2} \mathrm{CO}_{3} \cdot \mathrm{Na}_{2} \mathrm{CO}_{3}$

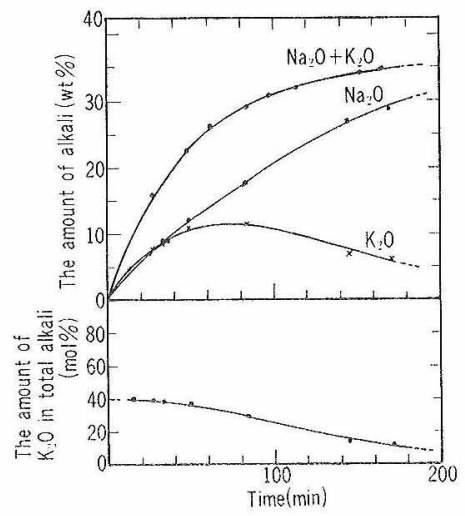

(b) in vapor of molten $\mathrm{K}_{2} \mathrm{CO}_{3} \cdot 4 \mathrm{Na}_{2} \mathrm{CO}_{3}$

Fig. 15. Changes of the amount of alkali picked up by the forsterite powder samples during exposure to vapor of molten $\mathrm{K}_{2} \mathrm{CO}_{3} \cdot \mathrm{Na}_{2} \mathrm{CO}_{3}$ and molten $\mathrm{K}_{2} \mathrm{CO}_{3} \cdot 4 \mathrm{Na}_{2} \mathrm{CO}_{3}$ at $1200^{\circ} \mathrm{C}$, respectively.

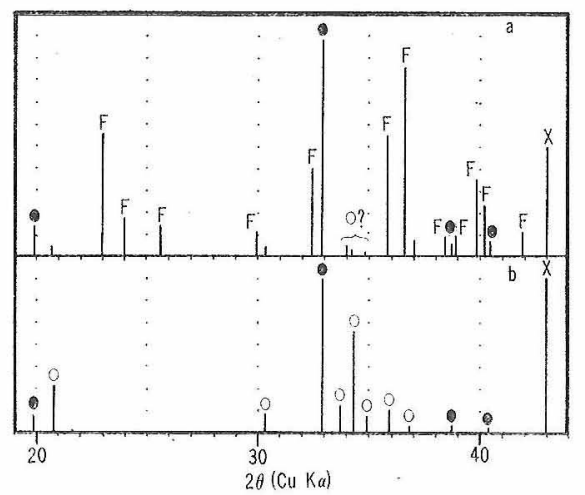

(a) $16.7 \mathrm{wt} \%$ alkali (b) $31.2 \mathrm{wt} \%$ alkali $\mathrm{F}$ : forsterite $x: \mathrm{MgO}$ : KMS $\mathrm{O}: \mathrm{N}_{2} \mathrm{M}_{2} \mathrm{~S}_{3}$-NMSss Fig. 16. X-ray diffraction patterns of the forsterite powder samples reacted with vapor of molten $\mathrm{K}_{2} \mathrm{CO}_{3} \cdot \mathrm{Na}_{2} \mathrm{CO}_{3}$ at $1200^{\circ} \mathrm{C}$.

回折図形である。

3.5.3 フォルステライト耐火物ブロックの炭酸塩混 合蒸気による侵蝕图-17 は， $1200^{\circ} \mathrm{C}$ で 30 時間 (1: 1）炭呀塩蒸気によって侵蝕されたフォルステライト面㣙 火物ブロックの侵蝕層部分の写真である，侵蝕層内部の

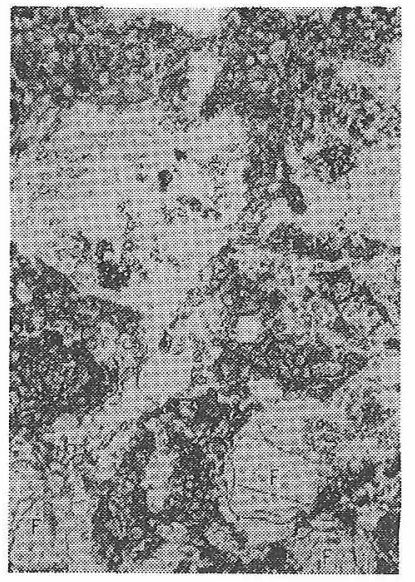

open nicol

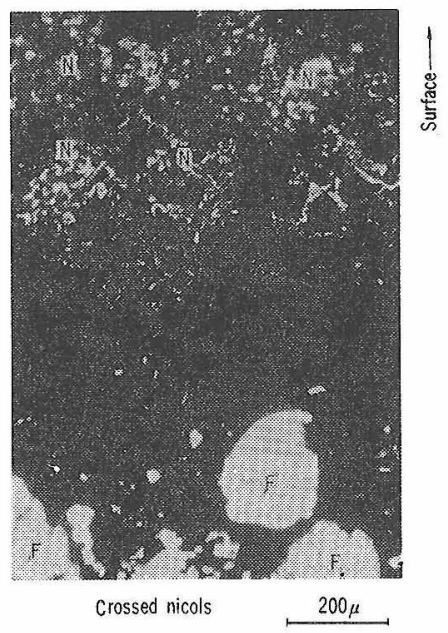

F : forsterite $\quad \mathrm{N}: \mathrm{N}_{2} \mathrm{M}_{2} \mathrm{~S}_{3}-\mathrm{NMS}$ ss

Fig. 17. Photomicrographs of the forsterite refractory attacked by vapor of molten $\mathrm{K}_{2} \mathrm{CO}_{3} \cdot \mathrm{Na}_{2} \mathrm{CO}_{3}$ at $1200^{\circ} \mathrm{C}$, for $30 \mathrm{hrs}$.

骨材フォルステライト周縁は，複屈折のない生成物（主

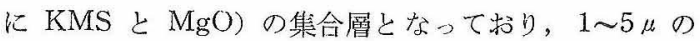
粒状ペリクレース結晶が散在している。 そして侵蝕がよ り進んだフォルステライトの消失した表面付近の部分で は， 2 軸性結晶 $\left(\mathrm{N}_{2} \mathrm{M}_{2} \mathrm{~S}_{3}-\mathrm{NMS} \mathrm{ss}\right)$ の生成がみられる。 それ杜，表面に近づくぼ゙複屈折の高いものになってい る.

\section{4. 考 察}

4.1 アルカリ混合蒸気について

$\mathrm{K}_{2} \mathrm{CO}_{3}, \mathrm{Na}_{2} \mathrm{CO}_{3}, \mathrm{~K}_{2} \mathrm{SO}_{4}$ 扩よび $\mathrm{Na}_{2} \mathrm{SO}_{4}$ のそれぞれ の高温に抢ける性質について, 最近では, 小杉 ${ }^{9}$ の詳細 な研究がある。

この研究によると, $\mathrm{K}_{2} \mathrm{SO}_{4}$ の熱解離生成物は, $\mathrm{K}_{2} \mathrm{O}$, $\mathrm{SO}_{2}, \mathrm{SO}, \mathrm{O}_{2}, \mathrm{~K}$ であり, $\mathrm{K}_{2} \mathrm{CO}_{3}$ のそれは, $\mathrm{K}_{2} \mathrm{O}, \mathrm{CO}_{2}$, $\mathrm{O}_{2}, \mathrm{C}, \mathrm{O}, \mathrm{K}$ であること, 抒よびその熱解離反応は, 
15 山口明良注か

つぎのようであると推定している。

$\mathrm{K}_{2} \mathrm{SO}_{4}$ の場合注, $\mathrm{K}_{2} \mathrm{SO}_{4} \longrightarrow \mathrm{K}_{2} \mathrm{O}+\mathrm{SO}_{2}+1 / 2 \mathrm{O}_{2}$

$\mathrm{K}_{2} \mathrm{CO}_{3}$ の埸合は, $\mathrm{K}_{2} \mathrm{CO}_{3} \longrightarrow \mathrm{K}_{2} \mathrm{O}+\mathrm{CO}_{2}$

一方, $\mathrm{Na}_{2} \mathrm{SO}_{4}$ の解離生成物法, $\mathrm{Na}_{2} \mathrm{O}, \mathrm{SO}_{2}, \mathrm{O}_{2}, \mathrm{SO}$, $\mathrm{Na}$ であり， $\mathrm{Na}_{2} \mathrm{CO}_{3}$ のそれは， $\mathrm{Na}_{2} \mathrm{O}, \mathrm{CO}_{2}, \mathrm{O}_{2}, \mathrm{C}, \mathrm{O}$, $\mathrm{Na}$ であること，またその解囄反応式は，

$\mathrm{Na}_{2} \mathrm{SO}_{4}$ の場合は, $\mathrm{Na}_{2} \mathrm{SO}_{4} \rightarrow \mathrm{Na}_{2} \mathrm{O}+\mathrm{SO}_{2}+1 / 2 \mathrm{O}_{2}$

$\mathrm{Na}_{2} \mathrm{CO}_{3}$ の場合は, $\mathrm{Na}_{2} \mathrm{CO}_{3} \rightarrow \mathrm{Na}_{2} \mathrm{O}+\mathrm{CO}_{2}$

となり，いずれの場合名一度解離反応が始杂ると, 解離 生成物はさらに低分子量の物質に解離するため, $\mathrm{K}, \mathrm{Na}$, $\mathrm{SO}, \mathrm{CO}$ 叔よざ $\mathrm{O}$ の生成は，アルカリ盐の解離生成物 の再解離によるとみなした方が適当で每ると結論してい 万。

そして、それぞれの解離定数について,小榇や Eyber ${ }^{10\rangle}$ の報告が女り，それより炭酸塩の $1200^{\circ} \mathrm{C}$, 战上ざ硫酸塩 の $1300^{\circ} \mathrm{C}$ での解離定数夌求方と，

$$
\begin{aligned}
& K_{p\left(\mathrm{~K}_{2} \mathrm{CO}_{3}\right)}=2.70, \quad K_{p\left(\mathrm{Na}_{2} \mathrm{CO}_{3}\right)}=3.2 \times 10^{-5} \\
& K_{p\left(\mathrm{~K}_{2} \mathrm{SO}_{4}\right)}=6 \times 10^{-6}, K_{p\left(\mathrm{Na}_{2} \mathrm{SO}_{4}\right)}=10^{-10}
\end{aligned}
$$

となりこの温度に就いて, $\mathrm{K}_{2} \mathrm{CO}_{3}$ は大部分解離して いるが，他の塩はほとんぼ解離していないことを示して いる。

しかしながら，同一塩のカリウム塩とナトリウム塩が 混合された場合の熱解離反応や生成物あるいは解離度な どについて，まだ明らかにされていないことが多く，3.1 の結果の融液中と蒸気中とに括ける $\mathrm{K}_{2} \mathrm{O} / \mathrm{Na}_{2} \mathrm{O}$ 比に差 異が生ずる原因を，明確な根扰に基づいて考察するため には, 今後さらに混合塩の性質を追究し, 詳細に検討す る必要があるが，この差異の生ずる实験結果は十分に信 頼できる事契であるので，これに基づいて，以下耐火物 質とアルカリ混合蒸気との反空について考察觉進方。

\section{2 アルカリ混含蒸気と耐火物質との反応について}

最初に、コランダムと炭酸塩混合蒸気との反応につい て考察すると，その常温での反岕生成物は $\mathrm{KAlO}_{2}$ と $\mathrm{NaAlO}_{2}$ で女りこの雨者妨同し構遙でクリストバライ 下型構造 ${ }^{11}$ 有するものの, 前者は多形を有せず常温で も立方晶系であるが, 一方, 後者は多形を有し, 常温で は三斜晶系（？）となる.しかし雨者は 3.2 .2 の結果に 示されるように, 常温では固溶体を形成しないものの, $1200^{\circ} \mathrm{C}$ では完全他固溶体老形成寸る.したがって, 3.2.10結果に示されるよらに, 初期に反応したアルカ リ中の $\mathrm{K}_{2} \mathrm{O}$ と $\mathrm{Na}_{2} \mathrm{O}$ の割合加，蒸気中のそれと一致す ることから考えて，最初に反応によって生成寸る化合物 は, 蒸気中の $\mathrm{K}_{2} \mathrm{O} / \mathrm{Na}_{2} \mathrm{O}$ 比䒚有する $\mathrm{KAlO}_{2}$ と $\mathrm{NaAlO}_{2}$ との固溶体，才なるち ( $\mathrm{K}, \mathrm{Na}) \mathrm{AlO}_{2}$ であると考えて よい。しかし，3.2.2 の結果で示されるよらに，力リウ 厶成分とナトリウム成分とが共存子る䨌囲気中では。 $\mathrm{KAlO}_{2}$ に比較して $\mathrm{NaAlO}_{2}$ が相当に安定であり，した がって ( $\mathrm{K}, \mathrm{Na}) \mathrm{AlO}_{2}$ が生成した後には，この固溶体
熏業協会誌 79 [11] 1971405

中の $\mathrm{K}$ と蒸気中の $\mathrm{Na}$ とぶ置撸されて， $\mathrm{Na}$ に富む占 溶体に変わる。 そして生成した固溶体は，冷却学通じて $\mathrm{NaAlO}_{2}$ 己 $\mathrm{KAlO}_{2}$ とに分離して析出势ることになる。

しかしながら，この反底過程で，前嘏 ${ }^{3)}$ の報告に岁る 単独鼠蒸気との反忘によって生成された

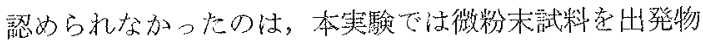
質として用いたため， $\beta$-アルミナから（K, Na) $\mathrm{AlO}_{2}$ 一 の反応が迅速で岁ったためと考えられる。

つぎに，ムライトとアルカリ炭酸塩混合繁気との反応 について考察する。 3.3.1〜2の実験結果によると，混 合蒸気との反底によって生成する化合物の大部分が， $\mathrm{NAS}_{2}$-NAss (力ーネギアイト固溶体) と KAS-KAss であり，他にはカルシライトが，反応初期のムライトの 残存している時にわずかに認められるのみであり，また 初期のムライトと反応したアルカリ中の $\mathrm{K}_{2} \mathrm{O} / \mathrm{Na}_{2} \mathrm{O}$ 比 は，蒸気中のそれとよく一致しているが，これらのこと から，その反応機構孛つぎの上らに考えてよからう。

すな⿰ら，最初にアルカリは，蒸気中の $\mathrm{K}_{2} \mathrm{O} / \mathrm{Na}_{2} \mathrm{O}$ 比でムライトと反応し，カルシライトの生成をへて，ム ライトの $\mathrm{Al}_{2} \mathrm{O}_{3} / \mathrm{SiO}_{2}$ 比を有し, 蒸氮中の $\mathrm{K}_{2} \mathrm{O} / \mathrm{Na}_{2} \mathrm{O}$ 比意有寸るカーネギアイト固溶体 $\left(\mathrm{N}_{3} \mathrm{~A}_{3} \mathrm{~S}_{2}\right)$ と KAS$\mathrm{KASS}\left(\mathrm{K}_{3} \mathrm{~A}_{3} \mathrm{~S}_{2}\right)$ との国溶体と都えてよい $(\mathrm{K}, \mathrm{Na})_{3}$ 。

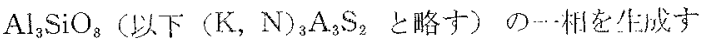
る.そしてこの四溶体は，3.3.3の結果て办されるよう に，常温飞扔いては完全な国溶体堂形成できないので, 冷却を通じ， $\mathrm{Na}$ 含有量の少ない $\mathrm{K}_{3} \mathrm{~A}_{3} \mathrm{~S}_{2}$ と $\mathrm{K}$ 含有墨: の少ない $\mathrm{N}_{3} \mathrm{~A}_{3} \mathrm{~S}_{2}$ とに分離して析出する。この場会, 前者恃多形圶有しないので立方晶として析出し, 後者は 転移して，常温では三斜晶系の結晶として析必すること になる。

この $\mathrm{K}_{3} \mathrm{~A}_{3} \mathrm{~S}_{2}$ への $\mathrm{N}_{3} \mathrm{~A}_{3} \mathrm{~S}_{2}$ の常温での固溶限界は 11 〜15wt\% であり, 一方, $\mathrm{N}_{3} \mathrm{~A}_{3} \mathrm{~S}_{2}$ への $\mathrm{K}_{3} \mathrm{~A}_{3} \mathrm{~S}_{2}$ への固 溶限界は明らかでないが， $\mathrm{NAS}_{2}$ に K がかなり固溶寸 ることから教えて， $\mathrm{N}_{3} \mathrm{~A}_{3} \mathrm{~S}_{2}$ 人も $\mathrm{K}$ 汃かなの程度固 溶できるすのと考えてよかろら。

そしてカリウムとナトリウムが共存する雾囲気中で は，3.3.3 の結果で示される上らに，カリウム化合物に 比較してナトリウム化合物が安定であり，したがって， $(\mathrm{K}, \mathrm{N})_{3} \mathrm{~A}_{3} \mathrm{~S}_{2}$ が生成した後には，この固溶体中の $\mathrm{K}$ と 蒸気中の $\mathrm{Na}$ とが置換されて，Naに富む固溶体に変わ る。その結果として反応が進んだ武料はど，冷却時にお いて $\mathrm{N}_{3} \mathrm{~A}_{3} \mathrm{~S}_{2}$ が多く析出する。これらのことからみて， ムライト・ブロックの侵蝕層がほほ 2 層に分か子て生成 し，表面付近部分にカーネギアイト固溶体が多量に析出 しているのは，その部分がアルカリとの反応時間が長 いため，上記の $\mathrm{Na}$ に富さ固溶体生成反岕が起ったた めと考觉らる。

つぎに，(1:1) 硫酸塩蒸気とムライトとの反応につい 
てみると，炭酸塩混合蒸気による反応に比較して非常に 遅くなり,生成化合物も炭酸塩蒸気に上る場合が, KAS$\mathrm{KAss}$ ，カーネギアイト固溶体呫よびごく少量のカルシ ライトであるのに反し，硫酸塩蒸気による場合には，コ ランダムが著しく生成し，他にカルシライト， $\beta$-アルミ ナ，カーネギアイト固溶体が生成し，KAS-KAss の生

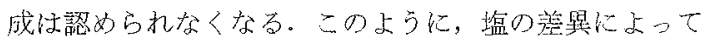
生成化合物に差異が生ずるのは，共存する $\mathrm{SO}_{2}$ 成分の 反応に抒上ぼす影響であると考光られるが，この影響の 様相は, 前報 ${ }^{12)}$ で単独塩の場合について報告したのをほ ぼ同じであると考卆てよいので，このことについての考 察沙省略寸る。

鼠後に、フォルステライトと炭竣塩混合蒸気との反応 亿ついて考察子る。

常温江冷却した場合の生成化合物は， $\mathrm{MgO}, \mathrm{KMS}$ 掠 よび $\mathrm{N}_{2} \mathrm{M}_{2} \mathrm{~S}_{3}-\mathrm{NMS}$ ss であるが，3.5.1 の実験結果で 示されるよらに， $1200^{\circ} \mathrm{C}$ で， $\mathrm{N}_{2} \mathrm{M}_{2} \mathrm{~S}_{3}$-NMS-KMS 化命物間のいずれの混合比でも固溶体を形成(ただし， $\mathrm{N}_{2} \mathrm{M}_{2} \mathrm{~S}_{3}$ の融点が約 $980^{\circ} \mathrm{C}$ で岁るので，この化合物の 多い混合物では液相を生成寸るで岁万ううするので，こ の反応機構はっぎの上らに考えられる。

まず, アルカリは蒝気中の $\mathrm{K}_{2} \mathrm{O} / \mathrm{Na}_{2} \mathrm{O}$ 比でフォルス テライトと反忘し，穴の比存する $\mathrm{N}_{2} \mathrm{M}_{2} \mathrm{~S}_{3}$-NMS と KMS の固溶体である立方晶の $(\mathrm{K}, \mathrm{Na})_{2 x} \mathrm{Mg}_{x} \mathrm{Si}_{10-x}$ 。 $\mathrm{O}_{20}(4 \leqq x \leqq 5)$ \{以下 $(\mathrm{K}, \mathrm{N}){ }_{x} \mathrm{M}_{x} \mathrm{~S}_{3}(2 \leqq x \leqq 3)$ と略 寸\}と $\mathrm{MgO}$ 定生成寸る。兄してこの固溶体は, さらに 反応が進むに伴って，前記コランダム拉よざムライトの 場合と同様に，固溶体中の $\mathrm{K}$ と蒸気中の $\mathrm{Na}$ とが置換 されて，Na に富む化合物仙変わる。またここで生成す 万 $(\mathrm{K}, \mathrm{N})_{x} \mathrm{M}_{x} \mathrm{~S}_{3}$ は常温では存在できず，椧却を通じ KMS と $\mathrm{N}_{2} \mathrm{M}_{2} \mathrm{~S}_{3}-\mathrm{NMSSS}$ に分離して（ただし，そ机 ぞれの化合物には，Na あるいは Kを劣程度固溶で きると考えられる) 前者性多形を有しないので立方晶と して析出し, 後者は転移して2 韩性結晶として析出する ことになる。

これらのことから，フォルステライト・ブロックの侵 蝕層の内部が複屈折のない愿であるのに反し, 表面付近 に複屈折のある結晶が生成するのは，その部分の反応時 閻が長く，その結果 $\mathrm{Na}$ に富む化合物が生成されて $\mathrm{N}_{2} \mathrm{M}_{2} \mathrm{~S}_{3}$-NMS SS がより多く生成されたためと考えられ る。

以上，コランダム，ムライトおよびフォルステライト のそれぞれとアルカリ炭酸塩混合蒸気との反忘について 考察した中には汃なり共通した反応機構を認好ることが でる。

すなわち，反応初期にそれぞれの而火物質と反店する $\mathrm{K}_{2} \mathrm{O}$ と $\mathrm{Na}_{2} \mathrm{O}$ の割合は, 蒸気中のそれとょく一致して 抢り，その組成比のナトリウムとカリウム走含有する固
溶体が形成され，この固溶体は，さらにアルカリ混合蒸 気と反忘してナトリウム亿富む圆溶体に変化することで ある。この場合, 初期に反応した $\mathrm{K}_{2} \mathrm{O}$ 飞 $\mathrm{Na}_{2} \mathrm{O}$ の割 合が，蒸気中のそれとよく一致するのは，各単独アルカ リ塩のみでも各試料とかなり反応寸るものであり，また 蒸気処理に際し, 試料の周囲に存在する $\mathrm{K}_{2} \mathrm{O}$ 々 $\mathrm{Na}_{2} \mathrm{O}$ の割合が，当然のことながら，蒸気中のそれと同じで岗 ることによるものと考えられる。この時, コランダムと の反応で $\beta$ アナルミナが，ムライトとの反応で加ルシラ イトが最初に生成しても，そ竌岵ただちにア゙ルカリを反

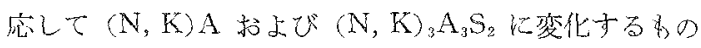

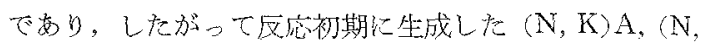
$\mathrm{K})_{3} \mathrm{~A}_{3} \mathrm{~S}_{2}$ および $(\mathrm{N}, \mathrm{K})_{x} \mathrm{M}_{x} \mathrm{~S}_{3}(2 \leqq x \leqq 3)$ は，ほ淩 気中の $\mathrm{K}_{2} \mathrm{O} / \mathrm{Na}_{2} \mathrm{O}$ 比䘮有するものとみなしてよからう。 そしてこれら固溶体は，アルカ少混合蒸気中では安定な ものでなく、いわば準安定なものと考光られ、つづいて 起乞る反応は，安定な $\mathrm{Na}$ 亿富む固溶体一の移行，すな わち生成圆溶体中の $\mathrm{K}$ と蒸気中の $\mathrm{Na}$ との置換による $\mathrm{Na}$ に富む固溶体の生成反底である。そして，ここで生 成した固溶体は，冷却老通し，カリウム化合物とナトリ ウム化合物に分離するが，カリウム化合物は多形存有し ないので, 常温では立方晶として析出し，ナトリウム化 合物は，転移定起こし他の結晶系となって析出する。し たがって反灾が進むに伴って，ナトリウム化合物が多く 生成されることになる。

以上の共通点加ら考えて，他の耐火物質とアルカり混 合蒸気上の反忘に赫いても，本実験で行なったものと本 質的にはか子り類似した反忘機構で离ると推察できる。

そして，笑際に使用されを湖火物のアルカリ蒸気仪よ る侵蝕に招いても，種々の要因が交錯して起こるため多 少のずれは予想されるものの，その侵蝕機構の大筋はか なり類似したものとなり, 初期には蒸気中のアルカリ比 で侵蝕されるものと考觉られる。

しかしながら，従来の研究1で，実際の操業時で耐火 物中に侵入した $\mathrm{K}_{2} \mathrm{O} / \mathrm{Na}_{2} \mathrm{O}$ 比住, 投入原料中の之の比 飞比較して大きく, $\mathrm{K}_{2} \mathrm{O}$ が耐火物中に邀択的汇残留富 化し，特に有害である々報告されているが，これは恐ら く上記の理由によって，东ず雲囲気中のアルカリ割合に 応じて反応した結果, 耐火物中に侵入した $\mathrm{K}_{2} \mathrm{O}$ が投入 原料中のそれよりも多くなったためであり， $\mathrm{K}_{2} \mathrm{O}$ と $\mathrm{Na}_{2} \mathrm{O}$ との反応性の差異沉よってたらされたものでは ないと考克られる。

\section{5. 総 括}

$1200^{\circ} \mathrm{C}$ に和ける $\mathrm{K}_{2} \mathrm{CO}_{3}$ 上 $\mathrm{Na}_{2} \mathrm{CO}_{3}$ の宸酸塩混合融

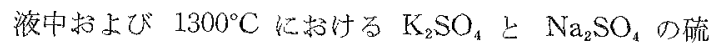
酸塩混合融液中と，それぞれから蒸発した蒸気中とにお ける $\mathrm{K}_{2} \mathrm{O}$ と $\mathrm{Na}_{2} \mathrm{O}$ の割合の関係を調べ，また去れに 
基づいて, コランダム，ムライト，フォルステライトの それぞれと，炭酸塩混合蒸気との反応㧍よびムライトと 硫踆塩混合蒝気との反応について調べた結果，つぎのこ とが明らかになった。

(1) 蒸気中の $\mathrm{K}_{2} \mathrm{O}$ と $\mathrm{Na}_{2} \mathrm{O}$ の割合は, 融液中の それに比し，相当に $\mathrm{K}_{2} \mathrm{O}$ に富むむのとなる。

（2）アルカリ炭酸塩混合蒸気亡, それぞれの耐火物 質との反応に拈いて，初期に反応する $\mathrm{K}_{2} \mathrm{O} / \mathrm{Na}_{2} \mathrm{O}$ 比は， 蒸気中のそれに一致しており，生成したアルカリ化合物 は, ナトリウム化合物とカリウム化合物の固溶体であ り，常渣ではそれそれれの化合物に分離して析出する。

（3）このアルカリ化合物を生成した後には，化合物 中の $\mathrm{K}$ 成分と蒸気中の $\mathrm{Na}$ 成分との置換反応が起こ り，反応の進行に伴い， $\mathrm{Na}$ に富む化合物に変化する。

(4) 硫酸塩混合蒸気との反店性, 炭酸塩混合蒸気と の反応に比して非常に緩慢であり，ムライト上の反応に 拈いて, 初期に反応寸る $\mathrm{K}_{2} \mathrm{O} / \mathrm{Na}_{2} \mathrm{O}$ 比は蒝気中のそれ に一致寸る。しかし反応の進行に伴いその比は小くな 万.
付記，この研究を竍告するにあたり，種及御指導いただいた

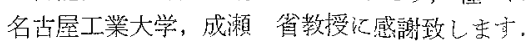

\section{文献}

1）田賀并秀火編 “続高温材料工学” 化学工業社 (1970) p. 60-63, p. 74-75.

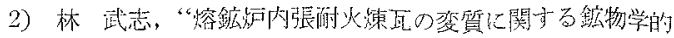
研究” p. 264-74(1960)(学位論文); 穼協 71, C 107(1963).

3）山口明良・大河原 晋・山中昭広, 㝘協 77 [11] 357-66 (1969).

4）山口明良, 窯協 78 [7] 237-49 (1970).

5）大河原 晋・山口明良, 呚協 76 [2] 29-36 (1968).

6）山上丨明良, 窝協 78[2] 74-75 (1970).

7) J.F. Schairer, N.L. Bowen, Am. J. Sci. 254, 129-95 (1956).

8）大河原 晋・山网明良, 媇協 77 [6] 208-16 (1969)

9）小杉哲夫, 工化 70 [11] 2089-93 (1967)，71 [10] 158186 (1968), 73 [1] $148-54(1970), 73$ [6] $1087-92$ (1970).

10) G. Eyber, Glastech. Ber. 33 [8] 283-85 (1960).

11) Tom. F.W. Barth, J. Chem. Phys. 3, 323-25(1935).

12）山口明良, 窝協 79 [4] 124-31 (1971).

(2/13/1971 受付) 